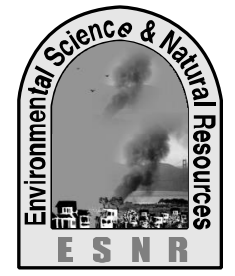

\title{
Performance Evaluation of Bari Inclined Plate Planter for Lentil Cultivation
}

\author{
M.R. Karim ${ }^{1}$, M.A. Gulandaz ${ }^{2}$, M.M. Mahmuda ${ }^{3}$ and M. Salahuddin ${ }^{4}$
}

${ }^{1}$ CIMMYT- Bangladesh, Jessore Hub, ${ }^{2}$ FMPE Division, Bangladesh Agricultural Research Institute, Gazipur-1701, ${ }^{3}$ Growing Together Project, VSO- Bangladesh and ${ }^{4}$ Seed Certification

Agency, Gazipur

*Corresponding author: gulandazfmpe.bari@gmail.com

\begin{abstract}
A field trial was carried out at Farm Machinery Technology Dissemination (FMTD) project site, Sujanagor, Pabna to test performance of planting methods with Bangladesh Agricultural Research Institute (BARI) inclined plate planter, BARI Bed planter over conventional manual planting method for sowing lentil during 2014-15. Mechanical planting method with BARI Inclined Plate Planter showed highest yield $\left(1.67 \mathrm{tha}^{-1}\right)$ whereas it was obtained 1.54 tha $^{-1}$ for bed planter and 1.41 tha $^{-1}$ for conventional manual planting method. Planting methods exhibited non significant response on yield attributes like number of plants population, plant height, seed pod $^{-1}$, dry weight of 10 plants and weight of 100 seeds. However, highest no. of pod plant ${ }^{-1}$ (168.83), primary branch (6.77) and secondary branch (33.67) was obtained from planting by IPP and these three parameters were shown lowest value (70.20, 3.5 and 11.8 respectively) in manual seeding methods. Total Cost of complete land preparation and planting was exhibited lowest for seed sowing with BARI Inclined Plate Planter (2016 Tk. ha ${ }^{-1}$ ) and it was 2727 Tk. ha ${ }^{-1}$ for BARI bed planter and highest for conventional manual seed sowing method (4433 Tk.ha $\left.{ }^{-1}\right)$.
\end{abstract}

\section{Introduction}

Lentil (Lens culinarisMedik.) is a legume that has been grown in the Mediterranean region since ancient times (Cokkizgin and Shtaya, 2013). The Fertile Crescent or west Asia is recognized as the centre of its domestication and diversity, where it is still an important winter-sown crop. It has now spread throughout Eurasia where it is grown mostly in the southern latitudes on calcareous soil types (Cokkizgin and Shtaya, 2013). The lentil plant is a dwarf (20ї 50 $\mathrm{cm}$ ), bushy annual with weakly upright to semi-vine growth, with similar appearance to the vetch plant. Lentil has a restricted root system, tending to lodge at maturity because of its weak stem. It has many soft, hairy branches with pinnately compound leaves and numerous oval leaflets. The broad, smooth pods range from 8 to $40 \mathrm{~mm}$ long and 6 to $15 \mathrm{~mm}$ wide. Each pod bears 1 ï 2 seeds and weight of 100 seeds ranges from 1.5 to $8.0 \mathrm{~g}$ (Ghanem et.al., 2015)

Lentil is a rising pulse crop grown with conventional tillage using extensive human labour at Pabna region. Traditional tillage is more time consuming for land preparation and sometimes causes late sowing which hampers in proper plants growth and eventually lower yield. Timely sowing of lentil not only increases yield and cropping intensity but also reduces turnaround time.

Conventional rice-wheat cultivation system produces greenhouse gases (GHG) through both biological process and burning of fuel by farm machinery. Tillage operations contribute $\mathrm{CO}_{2}$ through rapid decomposition of organic matter. Experiments have shown that every liter of diesel fuel used by tillage machinery contributes $2.6 \mathrm{~kg} \mathrm{CO}_{2}$ to the atmosphere. Diesel use remains a great source of GHG (Grace, 2003).

Traditional tillage method requires more time for land preparation which causes moisture loss or clod formation. Every crop has its optimum time of sowing/planting. Yield reduces remarkably due to late sowing/planting. Mechanical planting/sowing directly keep contribution in timely sowing which not only increase yield and cropping intensity but also reduces turnaround time. Conservation technologies have replaced the frequent tillage operations.

Reduced or minimum tillage is one kind of resource conservation technology which conserve natural moisture into the soil, add previous crop residues as well as increases quantity of organic matter in soil. As a circumspect, the water holding capacity of soil increases and it deficits irrigation water requirement. Conservation technology has been widely adopted in USA, Australia. Brazil, UK, Switzerland, Spain. Germany, Bolivia, Equator, India and other countries. Research results in the last 20 years showed, potential benefits of the technology from an environmental and economic point of view. The major benefit of reduced tillage is the reduction of production cost. Land preparation is one of the major charges for crop cultivation. Additional benefit in income is obtained through higher yield (Hobbs, 2003). 
Reduced or minimum tillage is a new tillage method to the farmers of Bangladesh. It is the step between conventional and no-tillage. It is becoming important to minimize the cost of land preparation, environmental pollution, maintain soil health and timeliness of operation. Pulse crops like lentil, Mungbean,blackgram etc. can be cultivated under minimum tillage. But the farmers of Bangladesh are still practicing broadcasting method of pulse seed sowing by conventional tillage. Small seeds like pulses and oilseeds are easy for continuous sowing. But it is very hard to sow the small seeds homogeneously and precession planting/sowing canô be controlled without mechanical sowing/planting. Fluted type seed metering devices are suitable for continuous sowing of small seeds. Inclined plate type seed metering device are suitable forboth small, large and rough surface seeds.

In conventional planting method placement of small seeds like pulse seed in certain depth and homogeneous seed placement is difficult whereas inclined plate type seed metering device are suitable to serve this purpose. Bangladesh Agricultural Research Institute (BARI) has developed inclined plate planter for minimum or reduced tillage operation (Ahmed et al., 2005; Matin et al., 2008). This method has been approached as initial field trial for different crop cultivation as initial field trial in some location of the country and seems promising. It is therefore deemed imperative to evaluate the relative performance of the mechanical sowing or planting method with inclined plate planter over conventional method at the farmersô field level. The planter was developed for one pass tillage and seeding operation by placing inclined plate metering device on BARI high speed rotary tiller (Wohab et al., 2011). The present experiment was conducted to fulfill the following objectives:

a) to evaluate the field performance of BARI inclined plate planter (set up with BARI high speed rotary tiller and bed former) in farmersôfield

b) to ascertain field efficiency and crop yield under these planting methods

\section{Materials and Methods}

The experimental trial was conducted at farmer's field of FMTD project site,Sujanagor, Pabna during 201415. One unitof power operated inclined plate planter and one unit of bed planter fabricated by Farm Machinery and Postharvest Process Engineering Division, BARI, Joydebpur, Gazipur was engaged for field performance test. The planter was tested for sowing lentil. Seed metering plates were made by using plastic material. The Specifications of the inclined plate planter and bed planter engaged for the field experiment was according to table 1. Before testing the planters in field, it was tested in OFRD, ARS, Pabna machinery testing field and the seed rate was calibrated as the following formula.

Table 1. The specification of BARI Inclined plate planter (IPP) and bed planter engaged for the field experiment

\begin{tabular}{|c|c|c|c|c|}
\hline $\begin{array}{c}\text { Diameter plate } \\
(\mathrm{mm})\end{array}$ & Thickness plate $(\mathrm{mm})$ & $\begin{array}{c}\text { Teeth numbers } \\
\text { of Plate }\end{array}$ & $\begin{array}{c}\text { The size of pinions } \\
\text { (Teeth) }\end{array}$ & $\begin{array}{c}\text { seed metering plate } \\
\text { inclination }\end{array}$ \\
\hline 130 & 5 & 32 & 19 & highly vertical position \\
\hline
\end{tabular}

\section{Field performance test}

Field performance test of the planter was conducted in farmers field located in Sujanagar, Pabna for sowing of lentil. The variety of lentil was BARI Moshur-5.The seeds were sown on 30 October 2014. There were three treatments as $\mathrm{T} 1=$ seed sowing with Inclined plate planter (IPP), T2= Seed sowing with Bed Planter (BP) and $\mathrm{T} 3=$ Conventional Manual seeding (MP).The experiment was laid out in randomized complete block design with three replication. Seed rate were $30 \mathrm{kgha}$ ${ }^{1}$ and line to line spacing was $30 \mathrm{~cm}$ for mechanical sowing and $33.75 \mathrm{kgha}^{-1}$ for manual sowing respectively. Tilling, bed formation, seed placement and laddering cum seed covering operations were done at a time in single pass of the machine. Time and cost required for complete land preparation and seed sowing by inclined plate planter and bed planter compared to traditional seeding were recorded.
According to Seed placement rate, germination rate was satisfactory because the field was fully at field capacity condition. During data collection there representative plot size was taken $33 \times 33 \mathrm{~cm}^{2}$ for plant population, $3 \mathrm{~m}^{2}$ for yield and then converted into ha. Depth of seed placement was measured after seed emergence by cutting 10 seedlings at the soil surface. A part of the stem that was inside the soil (from soil surface to seed remnants on the roots) was taken out and its length was measured which is considered as the depth of seed placement. M.C (\%) was measured by automatic penetration type moisture meter. Irrigation, fertilizing, weeding and all other intercultural operations were done properly and timely. The crop was harvested on 17 February 2015. Data on yield and yield contributing characters were collected at harvesting stage and analyzed statistically. Mean comparison were adjudged using least significant differences at the $5 \%$ level of the probability. 


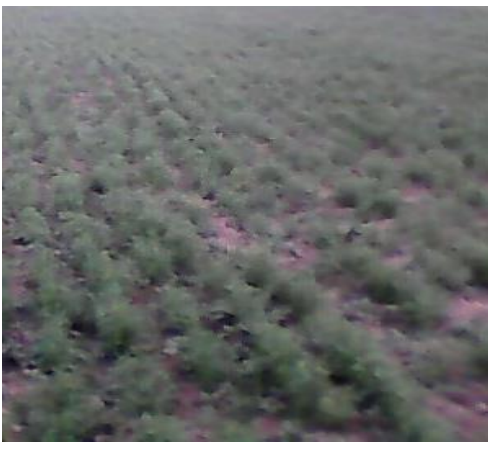

$T_{1}=$ Inclined Plate Planter

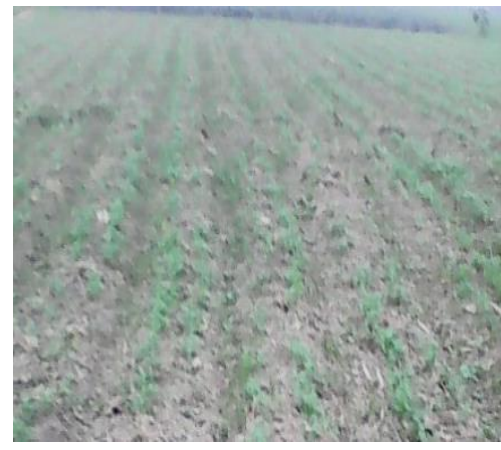

$\mathbf{T}_{2}=$ Bed Planter

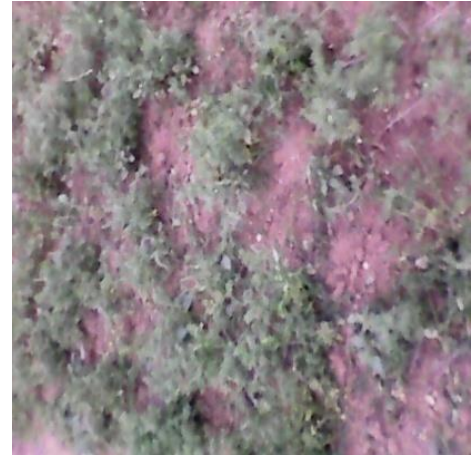

$\mathbf{T}_{3}=$ Manual seeding

Fig. 1. Picture of different Treatment of Lentil sowing in the field

\section{Seed Calibration Test}

Before the field performance test, it was tested in OFRD, ARS, Pabna machinery testing field and seed rate of lentil was calibrated by operating it for $20 \mathrm{~m}$ liner distance according to following formula:

$\mathrm{W}_{\mathrm{ts}}=\mathrm{C} \times \mathrm{W}_{\mathrm{C}} \times \mathrm{R}_{\mathrm{S}}$

Where,

$\mathrm{W}_{\mathrm{ts}}=$ Total Weight of seed (gm) which will have to drop through all

Lines for $20 \mathrm{~m}$ liner distance during PTOS single pass. $\mathrm{C}=$ Constant, which valued 2 for $20 \mathrm{~m}$ liner distance $\mathrm{W}_{\mathrm{C}}=$ Total width of cut $(\mathrm{m})$

$\mathrm{R}_{\mathrm{S}}=$ Total seed rate $(\mathrm{kg} / \mathrm{ha})$

\section{Results and Discussion}

The field performance of BARI inclined plate planters for lentil sowing compared to traditional broadcast seeding practice in Sujanagar, Pabnais shown in Table 2, 3 and 4 respectively. The field efficiency was tested at farmers field and it indicated that highest efficiency was noted in inclined plate planter (IPP) followed by bed planter with inclined plate $\left(\mathrm{T}_{2}\right.$ ). From table 2 it is shown that the lowest field efficiency was observed in manual method of seeding (T3).Relatively higher field efficiency was attained from IPP might be the reason of more area tillage (120 cm width of cut) and four row planting of seeds at a time due to its special instrumental set up with wider rotary as compared to bed planter (60 cm width of cut) and conventional seeding method by $2 \mathrm{WT}(60 \mathrm{~cm}$ width of cut).However, in manual seeding method usually different operations for land preparation, seed sowing, laddering and seed covering are done separately by several labours step by step which are time consuming, highly expensive and eventually showed less field efficiency. The depth of seed placement under different methods did not show significant variation statistically but from numerical value it is found that, seeds are placed relatively in higher soil depth in manual seeding than mechanical methods. Moisture content percentage (M.C. \%) values of soil in root zone at 7 days after sowing varied significantly and it was found lowest in bed planting $\left(\mathrm{T}_{2}\right)$ than other two methods. It was probably due to the trapezoidal shape of bed and large sunlight and air contact opened surface area which helps in accelerating the moisture release from soil. Percentage of disease infestation particularly root rot was also found in significant level and it was higher in conventional methods than mechanical planting methods.

Table 2. Field efficiency, depth of seed placement, M.C (\%) of soil in root zone depth at 7 DAS and Root rot infestation $(\%)$ under different planting methods at sujanagor, pabna during 2014-15

\begin{tabular}{|c|c|c|c|c|}
\hline Treat & $\begin{array}{c}\text { Field Efficiency } \\
(\text { ha/hr) }\end{array}$ & $\begin{array}{c}\text { Depth of seed } \\
\text { placement }(\mathrm{cm})\end{array}$ & $\begin{array}{c}\text { M.C (\%) of soil in root zone } \\
\text { at 7 DAS (mm) top to bottom }\end{array}$ & $\begin{array}{c}\text { (\%) Disease } \\
\text { infestation (Root rot) }\end{array}$ \\
\hline $\mathrm{T}_{1}$ & $0.1233 \mathrm{~A}$ & 1.9667 & $20.66 \mathrm{~A}$ & $1.66 \mathrm{C}$ \\
\hline $\mathrm{T}_{2}$ & $0.0587 \mathrm{~B}$ & 1.7333 & $13.33 \mathrm{~B}$ & $3.67 \mathrm{~B}$ \\
\hline $\mathrm{T}_{3}$ & $0.0347 \mathrm{C}$ & 2.7333 & $23.66 \mathrm{~A}$ & $9.33 \mathrm{~A}$ \\
\hline $\mathrm{LSD}(0.05)$ & 0.0233 & $\mathrm{NS}$ & 4.39 & 1.534 \\
\hline $\mathrm{CV}(\%)$ & 11.06 & 36.84 & 7.85 & 10.78 \\
\hline
\end{tabular}

T1 = seed sowing with Inclined plate planter (IPP), T2= Seed sowing with Bed Planter (BP) and T3= Conventional manual seeding (MP). 
From table 3 it is found thatplanting methods exhibited non-significant response on yield attributes like number of plants population, plant height, seed $\operatorname{pod}^{-1}$, and dry weight of 10 plants and weight of 100 seeds. However, highest no. of pod plant-1, primary branch and secondary branch was obtained from planting by IPP and these three parameters were shown lowest value in manual seeding methods. The yield did not show significant difference due to different planting methods statistically but it was numerically higher in IPP method than other two. Probably it was due to homogeneous seed placement at optimum soil depth and proper seed covering which help better nutrient supply for optimum plant growth and eventually higher yield.

Table 3. Yield components and yields of lentil as influenced by planting methods at Sujanagor, Pabna during 2014-15

\begin{tabular}{|c|c|c|c|c|c|c|c|c|c|}
\hline Treat & $\begin{array}{c}\text { No.of plant } \\
\text { population } \\
(33 \times 33 \mathrm{~cm} 2)\end{array}$ & $\begin{array}{c}\text { Plant } \\
\mathrm{Ht}(\mathrm{cm})\end{array}$ & $\begin{array}{c}\text { Wt of 100 } \\
\text { seed }(\mathrm{gm})\end{array}$ & $\begin{array}{c}\text { Pods/ } \\
\text { plant }\end{array}$ & $\begin{array}{c}\text { Seed/ } \\
\text { pod }\end{array}$ & $\begin{array}{c}\text { Dry wt. of } \\
10 \text { plants } \\
(\mathrm{gm})\end{array}$ & $\begin{array}{c}\text { Primary } \\
\text { branch }\end{array}$ & $\begin{array}{c}\text { Secondary } \\
\text { branch }\end{array}$ & $\begin{array}{c}\text { Yield } \\
(\mathrm{t} / \mathrm{ha})\end{array}$ \\
\hline IPP & 36.67 & 45.00 & $1.8000 \mathrm{~A}$ & $168.83 \mathrm{~A}$ & 1.6833 & 6.2 & $6.77 \mathrm{~A}$ & $33.67 \mathrm{~A}$ & $1.6720 \mathrm{~A}$ \\
\hline $\mathrm{BP}$ & 35.67 & 42.43 & $1.2333 \mathrm{AB}$ & $102.13 \mathrm{~B}$ & 1.5 & 5.7267 & $4.67 \mathrm{~B}$ & $15.5 \mathrm{~B}$ & $1.5350 \mathrm{AB}$ \\
\hline MP & 33.00 & 46.70 & $0.6733 \mathrm{~B}$ & $70.20 \mathrm{~B}$ & 1.5833 & 3.7967 & $3.5 \mathrm{~B}$ & $11.8 \mathrm{~B}$ & $1.4140 \mathrm{~B}$ \\
\hline LSD $(0.05)$ & $\mathrm{NS}$ & $\mathrm{NS}$ & 0.632 & 35.534 & $\mathrm{NS}$ & $\mathrm{NS}$ & 1.94 & 14.93 & 0.1488 \\
\hline $\mathrm{CV}(\%)$ & 4.14 & 4.35 & 17.55 & 10.73 & 8.5 & 25.65 & 13.42 & 25.23 & 3.32 \\
\hline
\end{tabular}

Table 4. Comparative study of BARI inclined plate planter with traditional broadcast seeding practice for complete land preparation and planting of lentil in Sujanagar, Pabna

\begin{tabular}{|c|c|c|c|}
\hline Particulars & $\begin{array}{c}\text { Inclined } \\
\text { plate planter }\end{array}$ & Bed Planter & $\begin{array}{c}\text { Traditional } \\
\text { practice }\end{array}$ \\
\hline No. of tillage for complete land preparation & 1 time & 1 time & 3 times \\
\hline $\begin{array}{l}\text { Tillage with general two wheel tractor (2WT) } \\
\text { Cost (TK/ha) }\end{array}$ & $\begin{array}{l}1 \text { time } \\
\text { (custom hire } \\
\text { service) } \\
\mathbf{3 0 0}\end{array}$ & $\begin{array}{l}1 \text { time } \\
\text { (custom hire } \\
\text { service) } \\
\mathbf{3 0 0}\end{array}$ & - \\
\hline Planting cost (Tk/ha) & $\mathrm{N} / \mathrm{N}$ & $\mathrm{N} / \mathrm{N}$ & 250 \\
\hline Laddering/Seed covering (TK/ha) & $\mathrm{N} / \mathrm{N}$ & $\mathrm{N} / \mathrm{N}$ & 750 \\
\hline $\begin{array}{l}\text { Time required for complete land preparation }((\mathrm{IPP} / \mathrm{BP}+2 \mathrm{WT}) \& \\
\text { Manual seeding }(2 \mathrm{WT})) \text { and planting }(\mathrm{hr} / \mathrm{ha})\end{array}$ & $8.5+1=9.5$ & $17+1=18$ & $\begin{array}{l}22.5+3.75= \\
29\end{array}$ \\
\hline Fuel consumption (lit/ha) & 11.25 & 18.75 & 22.5 \\
\hline Cost (Tk/ha)@Tk. 68.12 & 766 & 1277 & 1533 \\
\hline Oil \& Lump sum cost (TK/ha) & 200 & 200 & 400 \\
\hline $\begin{array}{l}\text { Operator cost (TK/ha ) } \\
\text { - (Driver @ } 500 \mathrm{Tk} / \mathrm{ha} \text { and Machine mate @ } 250 \mathrm{Tk} / \mathrm{ha} \text { for IPP) } \\
\text { - (Driver @ } 600 \mathrm{Tk} / \mathrm{ha} \text { and Machine mate @ } 350 \mathrm{Tk} / \mathrm{ha} \text { for BP) } \\
\text { - (Driver @ } 1000 \mathrm{Tk} / \mathrm{ha} \text { and Machine mate @ } 500 \mathrm{Tk} / \mathrm{ha} \text { for MP) }\end{array}$ & 750 & 950 & 1500 \\
\hline Total Cost of complete land preparation and planting (Tk/ha) & 2016 & 2727 & 4433 \\
\hline
\end{tabular}

From table 4 it is found that no. of tillage was one for IPP and BP after one tillage with general two wheel tractor (2WT) but in traditional practice it was done for 3 times only by $2 \mathrm{WT}$.From table 4 it has been also found that, time consumption for land preparation and sowing is about half for IPP and one-third for BP in comparison to traditional manual seeding. Fuel is required about double for $\mathrm{BP}$ and triple for manual seeding than IPP. There is no significant difference of cost for complete land preparation and planting between IPP and BP but it is 1.6 to 2.2 times lower than conventional methods respectively.

Fig. 2 shows that grain yield is higher in seeding under inclined plate planter $\left(1.672 \mathrm{t} \mathrm{ha}^{-1}\right)$ and bed planter $\left(1.535 \mathrm{t} \mathrm{ha}^{-1}\right)$ whereas lower yield is $\left(1.414 \mathrm{tha}^{-1}\right)$ shown under manual planting methods. 


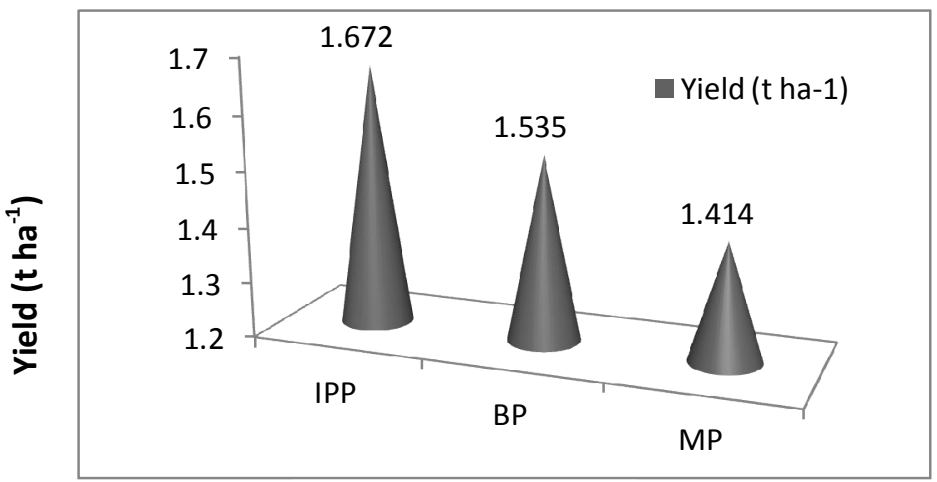

Planting methods

Fig. 2. Yield of lentil increase under mechanical planting methods as compared with conventional manual seeding

\section{Relationship among field efficiency of different planting methods and yield traits of Lentil}

The relationship of field efficiency of different planting methods with plant population, disease (Root rot) infestation percentage, pod plant ${ }^{-1}$, Branch and yield of Lentil is presented in Fig.3. From this figure, it is indicated that field efficiency of different planting methods showed negative relationship with disease infestation (\%) particularly root rot (Fig. 3B). It means

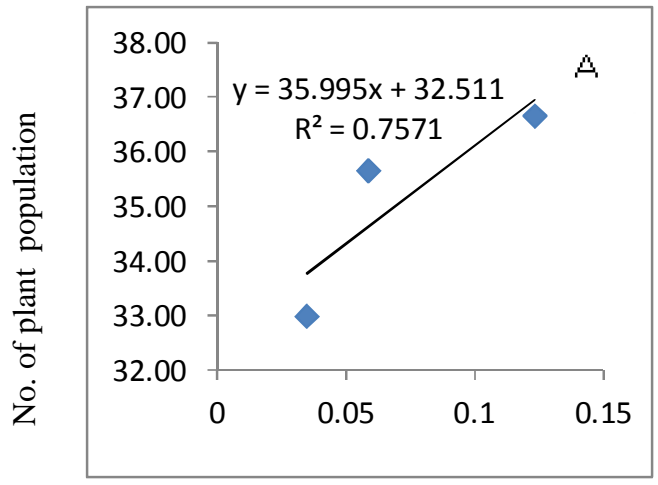

Field efficiency (ha hr ${ }^{-1}$ )

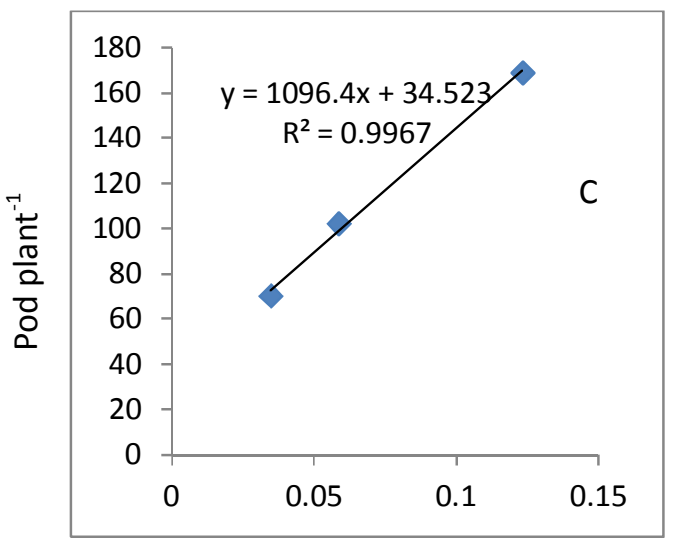

Field efficiency (ha hr ${ }^{-1}$ ) that if field efficiency increases (in case of mechanical planting) the disease (Root rot) infestation percentage decreases. On the other hand, podplant ${ }^{-1}$,no. of branches and yield shows positive relationship with field efficiency and rich value of regression co-efficient $\left(\mathrm{R}^{2}=0.996,0.99\right.$ and 0.95 respectively) is observed (Fig. 3C,3D,3E,3F). It is also showed that the relation is positive for plant population though value of regression co-efficient $\left(R^{2}=0.757\right)$ is poor (Fig. $\left.3 A\right)$.

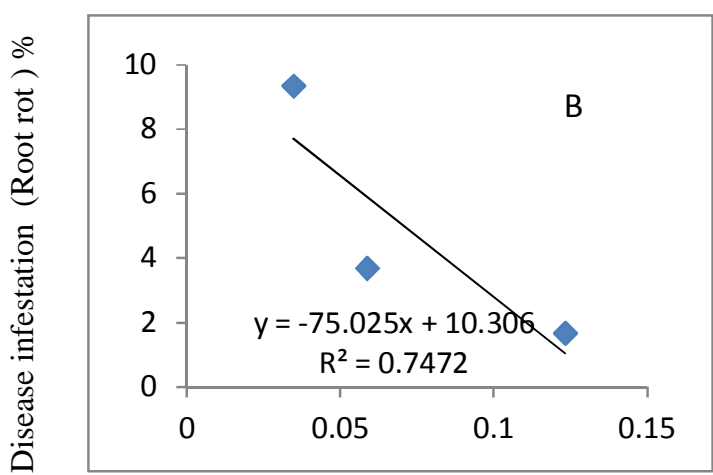

Field efficiency (ha hr ${ }^{-1}$ )

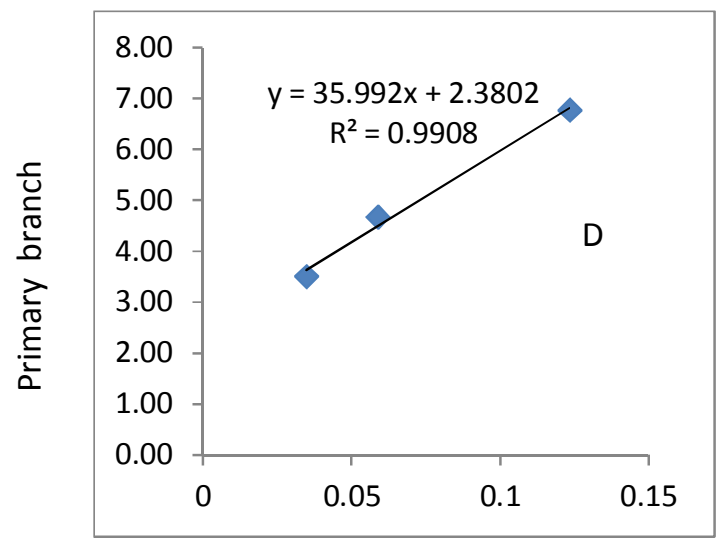

Field efficiency (ha hr ${ }^{-1}$ ) 


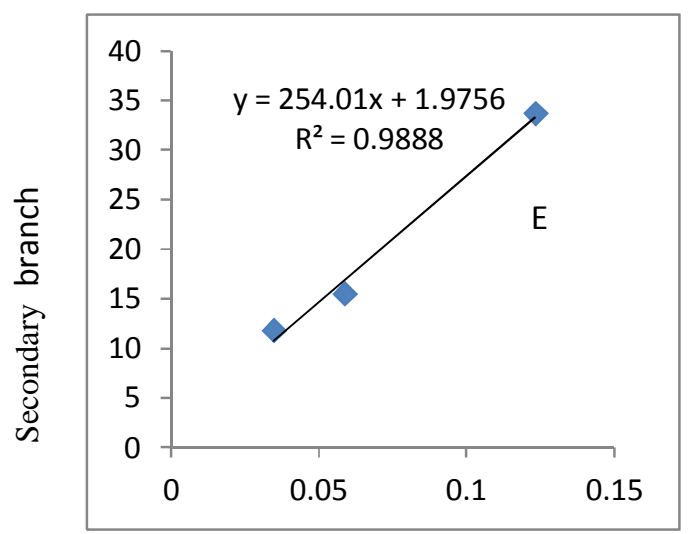

Field efficiency $\left(\mathrm{ha} \mathrm{hr}^{-1}\right)$

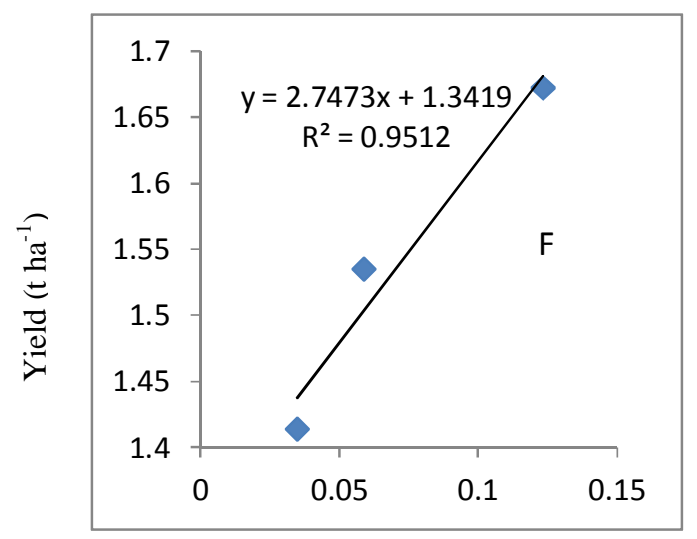

Field efficiency $\left(\mathrm{ha} \mathrm{hr}^{-1}\right)$

Fig. 3. Relationship of field efficiency of different planting methods with plant population, disease infestation (Root rot), pod plant ${ }^{-1}$,Branch and yield of Lentil.

\section{Conclusions}

The performance of planting methods significantly influence on lentil yield.Mechanical planting methods (IPP and BP) found promising for increasing lentil yield.Mechanical planting can save fuel, land preparation and seeding cost, time, money, human drudgeryandcan play an important role in maintaining soil health through reduced tillage and can increase cropping intensity by reducing turnaround time. The field efficiency of mechanical planting/seeding was relatively higher than conventional planting/seeding and showed positive relationship with yield trait and yield of lentil. Therefore, at the circumstances of agricultural labor shortage adoption of mechanical planting would be a viable technological option for raising lentil production at the field level.

\section{References}

Ahmed,S.,M.A.Matin,K.C.Roy,M.N.Amin,M.S.Islam and M.S.Islam.2005.Field performance of power tiller operated planter for maize, wheat and pulse crops. Annual ResearchReport,BARI.
Cokkizgin A. and M. J. Y. Shtaya. 2013.Lentil: Origin, Cultivation Techniques, Utilization and Advances in Transformation. Agricultural Science Volume 1, Issue 1 (2013), 55-62 ISSN 2291-4471 E-ISSN 2291-448X Published by Science and Education Centre of North America (C) Science and Education Centre of North America 55

Hobbs,R.P.2003. Is conventional tillage is essential for wheat. In Addressing ResourceConservation Issues in Rice-Wheat Systems of South Asia: A Resource Book. Rice-Wheat Consortium for the Indo-Gangetic Plains, International Maize and WheatImprovement Centre, New Delhi.Pp. 95100 .

Ghanem M. E., H. Marrou , C. Biradar, T.R. Sinclair. 2015. Production potential of Lentil (Lens culinarisMedik.) in East Africa. Agricultural Systems, 137, 24ї 38

Matin, M.A., M.S.Islam and M.Amin.2008. Demonstration of BARI power tiller operated planter for soybean and maize. Annual Research Report,BARI. 